\title{
CONCEPT OF PRESENT PRACTICE IN CHOOSING OF OPTIMAL NUMBER OF TUGS
}

\author{
Rino Bošnjak, Zvonimir Lušić, Filip Bojić, Dario Medić \\ University of Split (Croatia)
}

\begin{abstract}
The common practice in world-wide ports is that they have determined procedures regarding number of required tugs depending usually on most important factors such as weather criteria and size of vessel. This article presents various rules for some ports which is defined in their Safety Management System and criteria in choosing optimum number of tugs and optimum bollard pull. It is also described how various towage requirements can be assessed through the use of maritime simulators and which parameters are important and how the same can be obtained and assessed. General guidelines will also be defined in the article which must be taken into consideration for optimal choosing of tug boats. The science method used in this article is known as comparative analyses between computation and simulation on simulator; results are presented in figure 10 . factors

Keywords: ship; optimal number of tugs; bollard pull; guidelines; external
\end{abstract}

\section{Introduction}

The influence of wind, current, waves and other external factors that cause unwanted movement of the ship should be compensated by the ship's propulsion systems (main propulsion and bow/stern thrusters if ship is equipped by same) or tugs. Due to mandatory rules in ports open for international marine traffic there is a common practice of taking ship tugs and this paper describes the methodology by which ship tugs are taken. The methodology by which the number of optimal tugboats is determined depends on the size, geographical characteristics of area where they are operating as well as the type of ships entering or leaving it. The practice of taking tugs for tankers and the practice of taking tugs for non-tankers is not the same because of danger regarding cargo transported on tankers compared to other types of ships. Thus more tugs increase safety in case of accidents with ships especially for those which are carrying high-hazard cargo for example dangerous goods described in IMDG code co $^{1,2}$.

Bow or stern thrusters are used when the bow or stern needs to be pushed towards the berth (berthing) or off the berth (un-berthing) or if required to turn 
the ship in limited space. New ships are mostly equipped with bow thrusters, however in some ports if not mandatory often berth without assistance of tugs. However, it is mandatory to take tugs in a port basin with limited manoeuvring space and heavy maritime traffic. Determining the optimal power and number of tugs is not uniform and usually different ports will have different requirements. In the absence of regulations, this shall be determined by the master of the ship in agreement with the pilot ${ }^{3)}$. In this article, an example is given which defines the number of required tugs.

\section{DIFFERENT TYPES OF TUG BOATS}

There are different types of tugs depending on purpose and type of propulsion systems:

- Conventional propulsion system

- Azimuth Stern Drive - ASD

- Tractor tug with Rudder Propellers

- Voith Water Tractor or Voith Schneider propulsion system

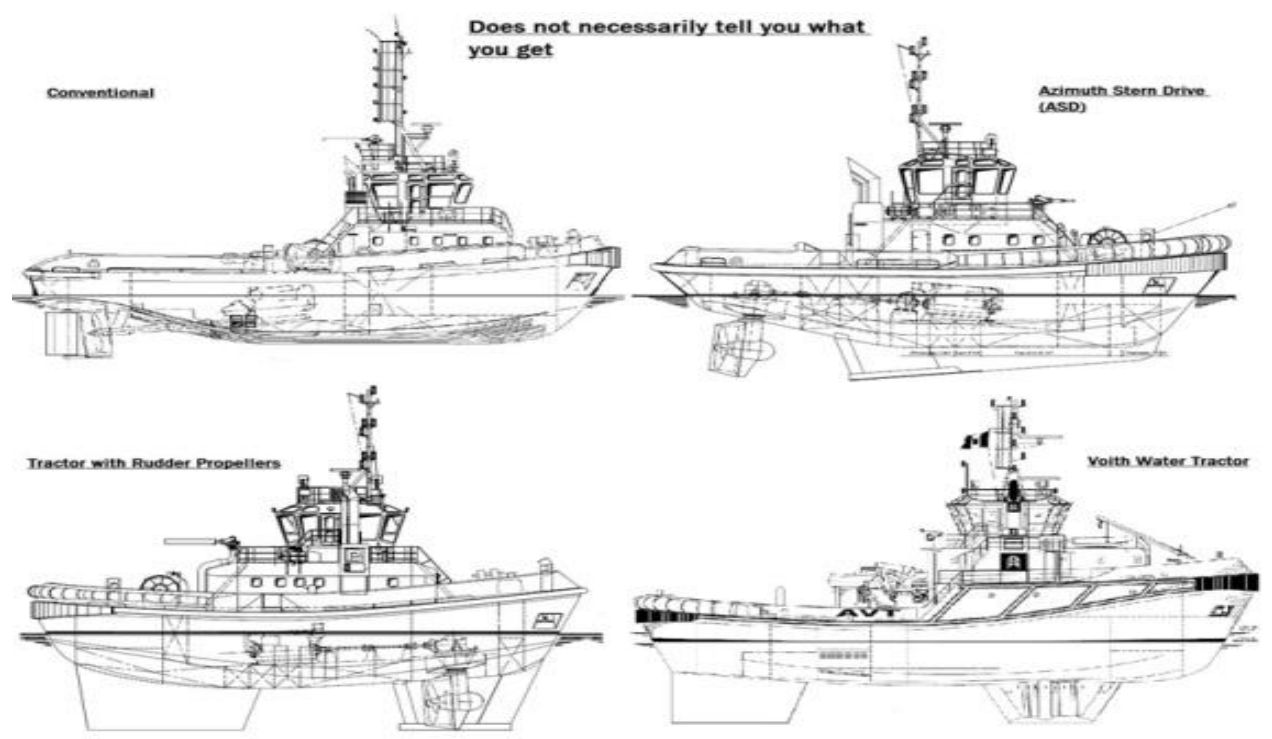

Figure 1. Underwater shape of tugs ${ }^{4)}$

In addition to the four most common propulsion systems described above, there is a "Rotor" tractor, which can be considered a further development of a tractor tug tractor which has two pre-assembled azimuth thrusters, a third azimuth thruster at the stern replacing the skeg. The second type of tug is 
the Combi tug, a modified single propeller with an additional azimuth bow thruster, in line with the main stern drive. It almost acts like a towing tractor. Conventional tractors are equipped with a standard drive system. There are variations of these types of tractors, mainly with a single or double screw, with a fixed nozzle and a steerable rudder or a steerable nozzle, and with a propeller with a fixed pitch or variable pitch. Conventional tugs connected to the stern of the assisted ship will have to operate in the traditional way (Figure 2.). This requires a lot of skill and experience from the tugboat commander, and is considered the most dangerous method of towing for such a tugboat, due to the high risk of tipping over to the side, which is called girting. Conventional tugs deliver the most power in the forward direction and will mainly be used as a bow tug on the anchor shafts (hawser). When connected to the stern of the assisted ship, they will operate effectively in a "conventional" manner, also called "stern to stern".

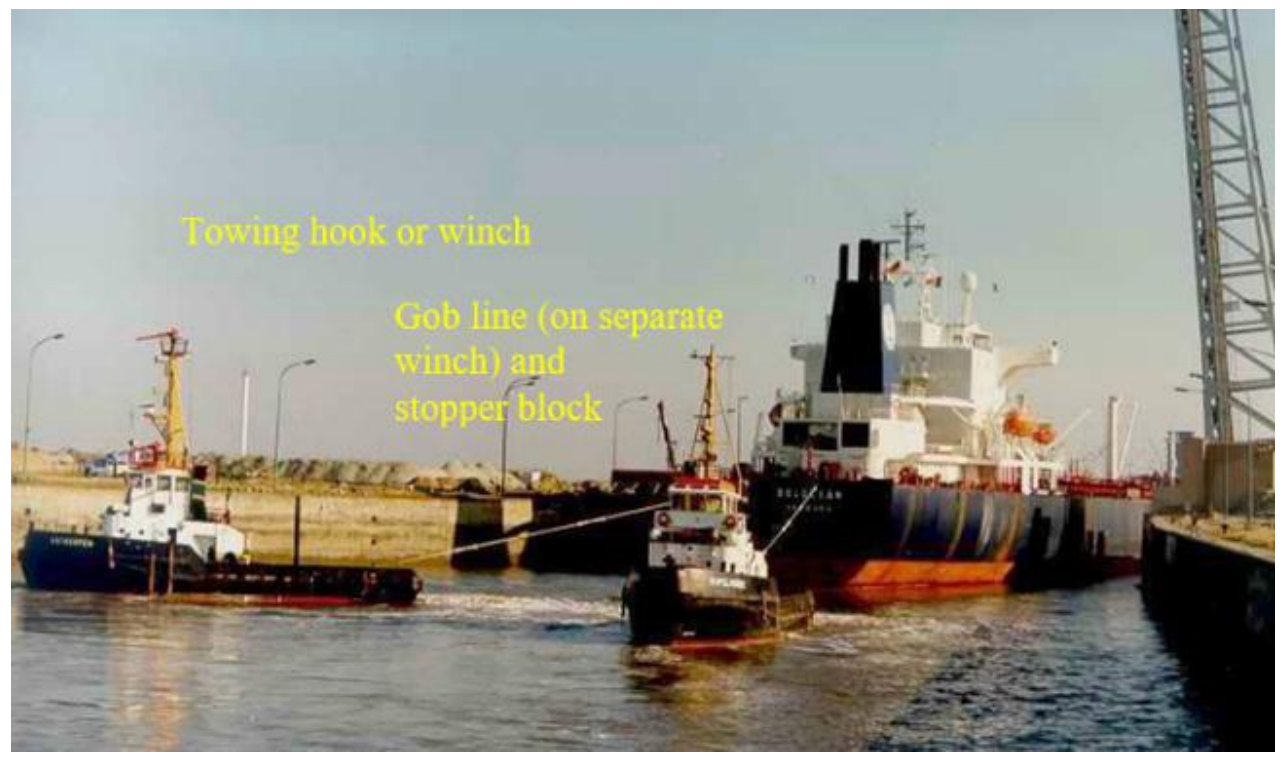

Figure 2. Conventional tug fast with stern of ship during assisting ${ }^{4)}$

The "towing point" will be moved away from the towing hook using the GobLine and the Stopper Block. The use of the Gob-Line is very important in order to avoid belting, i.e. capsizing the tractor. Azimuth Stern Drive - ASD tractors are equipped with two stern thrusters. The thrusters can be rotated independently by $360^{\circ}$ ("azimuth propulsion"), so that the propeller thrust can be directed in any direction. 


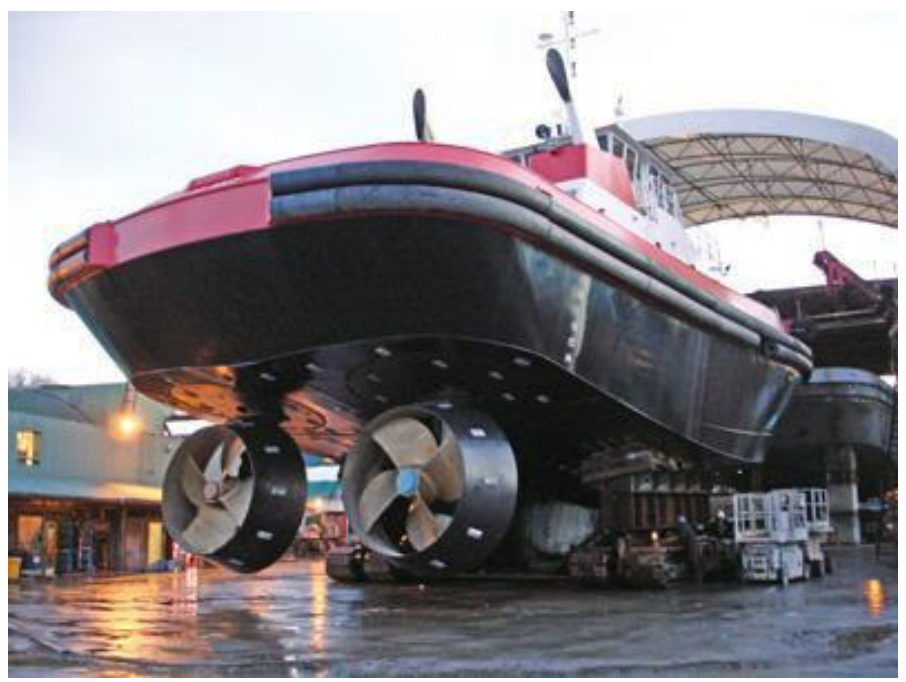

Figure 3. Azimuth thrusters on the stern ${ }^{4)}$

Rotor tractors are primarily tractor tractors with a third drive unit of $360^{\circ}$ below the stern, to further improve manoeuvrability and transverse traction.

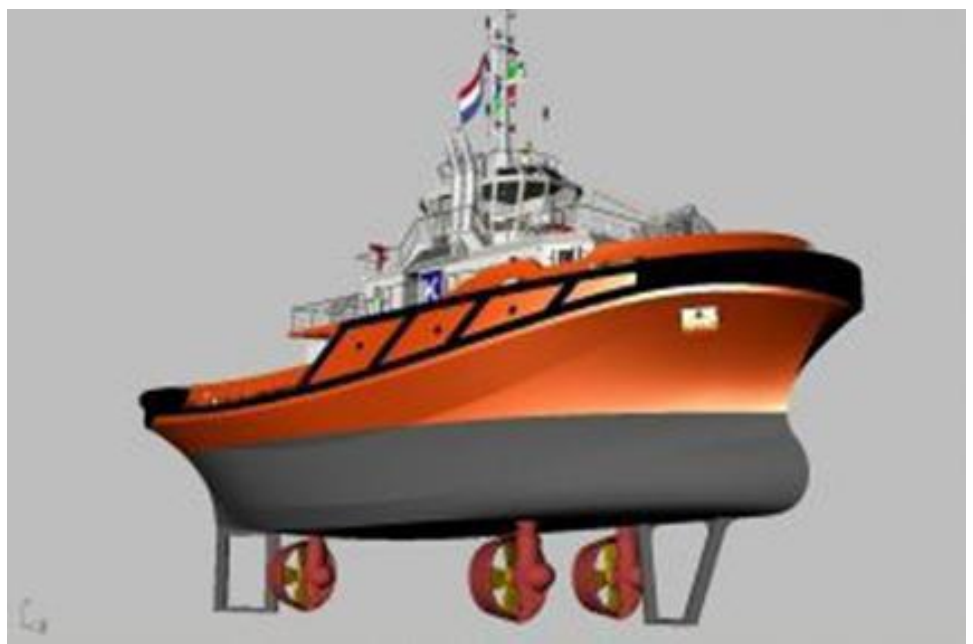

Figure 4. Rotor tug with 3 rudder-propellers ${ }^{4)}$

Combi tug - the main propulsion unit is located at the stern, with an azimuth thruster mounted on the bow and in line with the main propulsion. 


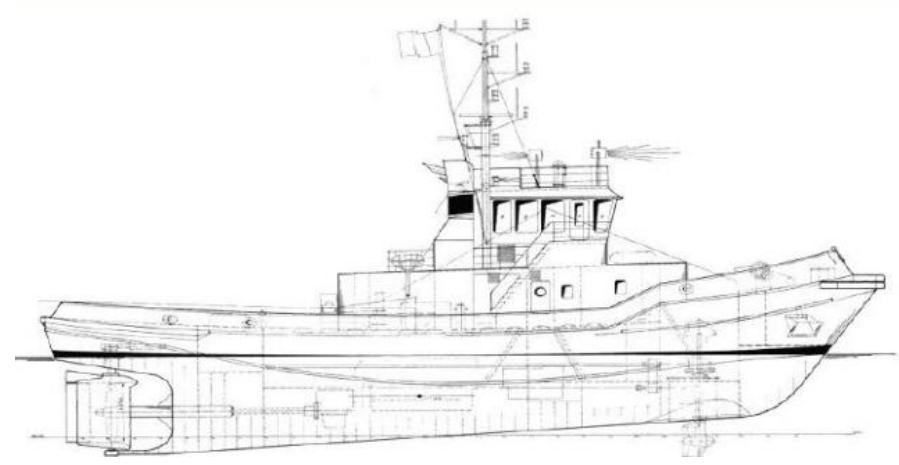

Figure 5. Combi tug with azimuth thruster bellow bow ${ }^{4)}$

\section{Obtaining of optimal bollard pull power of tug}

The towing service appears in the form of a port towing to assist in mooring, unmooring or maneuvering in general and assisting ships in case of emergency. Port tugs are with very good maneuverability with an average length of about 30 $\mathrm{m}$, a power of $1,000-4,000 \mathrm{~kW}$, and a towing force of 15 to $70 \mathrm{t}$, depending on the power and type of propulsion. Older-generation of tug tractors usually have fixed thrusters and rudders, and newer generation have azimuthal and cycloid thrusters.

Some of examples are shown here:

\begin{tabular}{|l|l|}
\hline Europort (Netherlands) & Bollard power $(\mathrm{t})=$ displacement $/ 3.000$ \\
\hline Japan & Bollard power $(\mathrm{t})=($ displacement $\times 60 / 100.000)+40$ \\
\hline Sweeden & Bollard power $(\mathrm{t})=$ Windage area of ship $\times$ speed $^{2} / 18.000$ \\
\hline
\end{tabular}

Table 1 shows the determination of the required tractor traction based on the above examples ${ }^{5}$.

Table 1. Obtaining of required bollard pull (t)

\begin{tabular}{|l|c|c|c|c|c|}
\hline Displacement (x1000) & 20 & 50 & 100 & 200 & 300 \\
\hline Europort & 7 & 17 & 33 & 67 & 100 \\
\hline Japan-Voith Schneider & 20 & 50 & 100 & 200 & 300 \\
\hline Japan & 52 & 70 & 100 & 160 & 220 \\
\hline Area (windage) (x1000) & 0,5 & 1 & 2,5 & 50 & 8,5 \\
\hline Sweden (wind of 15 m/s) & 6 & 13 & 31 & 63 & 106 \\
\hline
\end{tabular}

Typical Bollard-Pull vector diagrams for different types of tugs are shown below, Figure 6. The length of the vector denotes the "force" that can be provided in 
the direction of the vector. Green: Conventional twin screw tug (with or without bow thrusters) - fixed propellers on horizontal axis. Red: Tractor tug - their diagram is much more "distributed" in all directions, with slightly more power delivered to the bow of ship and to stern. Blue: Azimuth Stern Drive sadness - when moving sideways, the thrust in that direction is significantly reduced.

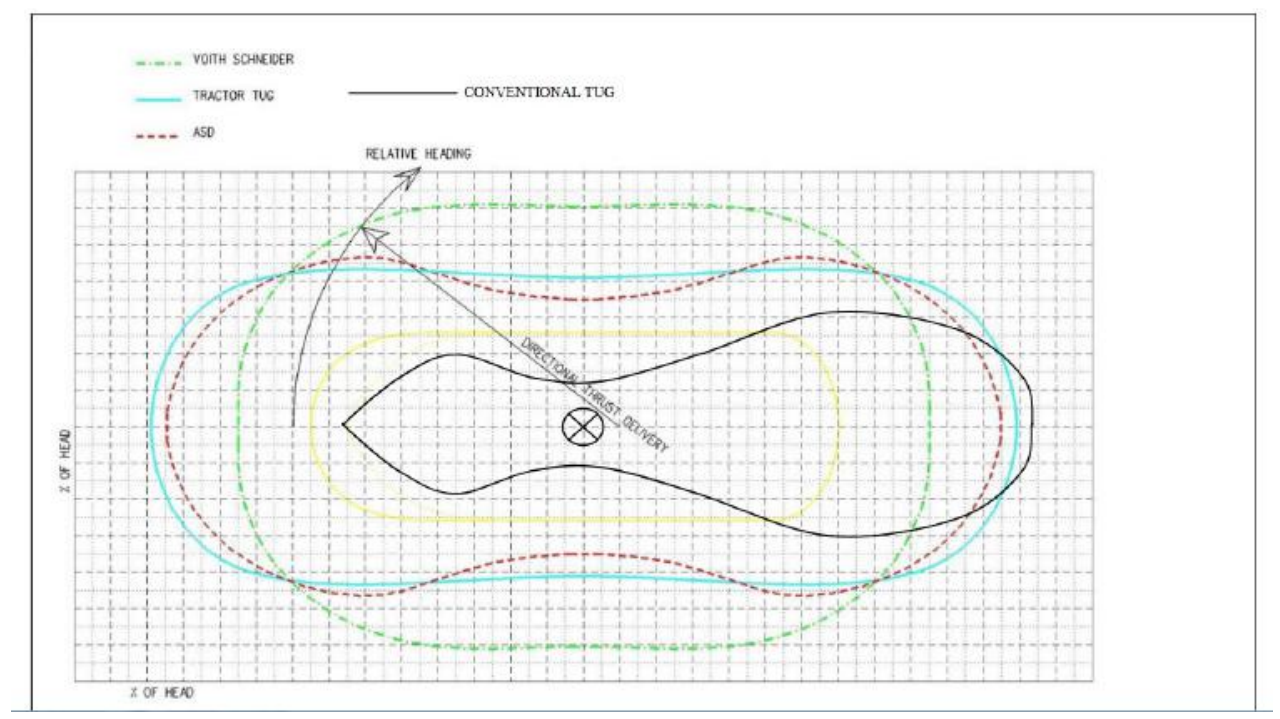

Figure 6. Bollard pull vector diagram for different types of propulsion ${ }^{6}$

Here are stated the factors which determining the choice of tug ${ }^{6}$ :

- Type of port and its approaches, predictable future events

- Existing environmental conditions

- Type of ships entering the port

- Common methods using the tugs in specific ports

- Available bollard pulls and experience of tug crew

- Available safety factors

- Available budget

- Maintenance

- Required training for tug's crew

- Consider use of tugs, when wind and current make difficult mooring condition

- Estimate the windage area of the ship exposed to wind or currents and to determine the number of tugs required

It is certainly recommended that the required power is calculated in accordance 
with the assessment of external factors for a particular type of ship, for a given area and the circumstances in which it operates, taking into account the appropriate safety margin ${ }^{7}$.

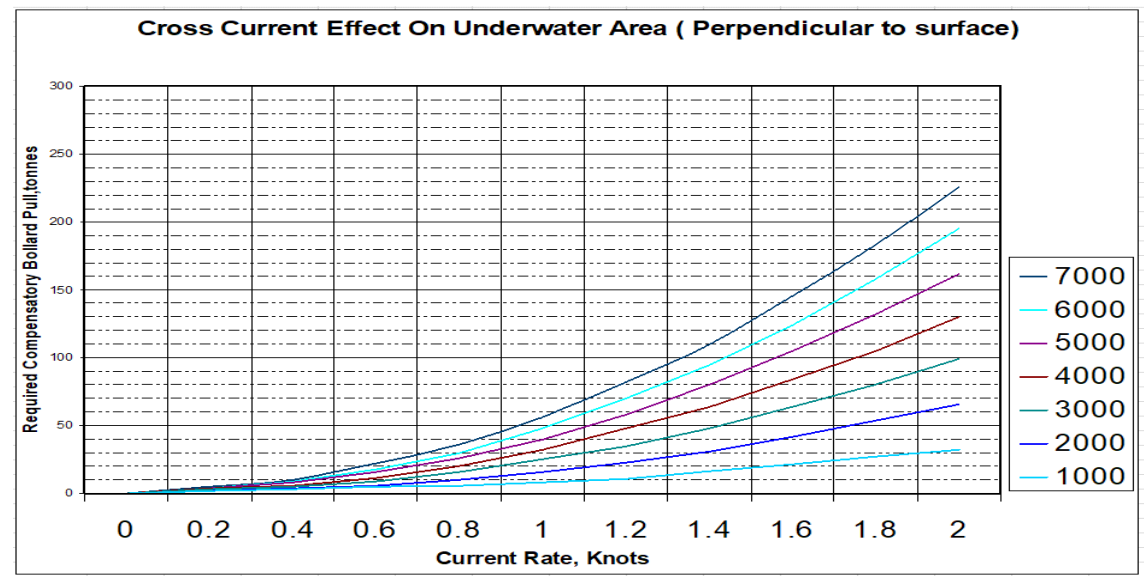

Figure 7. Required force (tbp) for compensation of side current effect ${ }^{7)}$

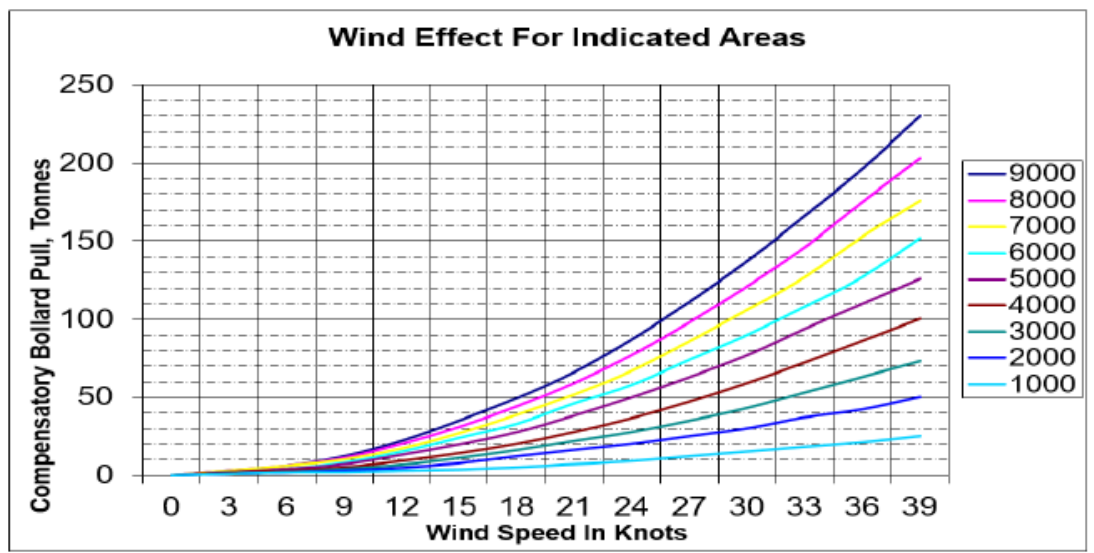

Figure 8. Required force (tbp) for compensation of wind effect ${ }^{7}$

Tug efficiency is affected by many factors, such as tug size, environmental harshness and towing speed. ND-0030 guideline offers a table for calculating the traction efficiency of tugs, where $\mathrm{H}=$ wave height. If the towing is continuous, the table gives the following values for the towing efficiency during the manoeuvring of the ship in port. 
Table 2. Efficiency of towing during manoeuvring of ship in port ${ }^{8)}$

\begin{tabular}{|c|c|c|c|c|c|}
\hline \multirow{2}{*}{$\begin{array}{l}\text { Bollard } \\
\text { Pull, in } \\
\text { tons }\end{array}$} & \multicolumn{5}{|c|}{ Tug efficiency $\%$} \\
\hline & $\begin{array}{l}\text { Calm } \\
\text { sea }\end{array}$ & $\begin{array}{l}\text { Wave } \\
\text { height } \\
(\mathrm{H})=2 \mathrm{~m}\end{array}$ & $\begin{array}{l}\text { Wave } \\
\text { height } \\
(\mathrm{H})=2 \\
\mathrm{~m}\end{array}$ & $\begin{array}{l}\text { Wave height } \\
(\mathrm{H})=3 \mathrm{~m}\end{array}$ & $\begin{array}{l}\text { Wave height } \\
(\mathrm{H})=>6 \mathrm{~m}\end{array}$ \\
\hline $\mathrm{BP} \leq 30$ & 80 & $50+B P$ & $\begin{array}{l}30+ \\
\mathrm{BP}\end{array}$ & $\mathrm{BP}$ & 0 \\
\hline $\begin{array}{l}\mathrm{BP}=30- \\
90\end{array}$ & 80 & 80 & $\begin{array}{l}52,5+ \\
\mathrm{BP} / 4\end{array}$ & $\begin{array}{l}7,5+0,75 x \\
\text { BP }\end{array}$ & insignificantly \\
\hline $\mathrm{BP} \geq 90$ & 80 & 80 & 75 & 75 & little \\
\hline
\end{tabular}

The calculations above given refer to the mathematical model of calculating the number of required tugs and their required bollard pull. Required bollard pull can be estimated on the basis of the impact of the external elements, primary wind, currents and waves. These elements are taken for the worst case scenario, usually lateral impact, and the obtained forces can be used as a reference value that tugs need to compensate. Below is one of the simpler models for calculating the impact of external forces on a ship.

\section{Models for calculating impact of external factors}

Wind impact as per formula ${ }^{5)}$ :

$F w=\frac{1}{2} \cdot C a \cdot \rho_{a} \cdot V r_{w} \cdot A$

Where are:

$\mathrm{FW}-$ wind force $[\mathrm{N}]$

$\mathrm{Ca}$ - coefficient of air resistance of a body exposed to wind (max 1$)$

$\rho \mathrm{a}$ - density of air $\left[\mathrm{kg} / \mathrm{m}^{3}\right]$

Vrw - relative speed of wind $[\mathrm{m} / \mathrm{s}]$

A - surface exposed to wind $\left[\mathrm{m}^{2}\right]$.

Impact of sea current as per formula:

$$
F c=\frac{1}{2} \cdot C_{w} \cdot \rho_{w} \cdot V_{S c}^{2} \cdot A_{c}
$$

Where are:

$\mathrm{Fc}$ - sea current force $[\mathrm{N}]$

$\mathrm{Cw}$ - water resistance coefficient (depends about depth/draft, usually between 1 and 5)

$\rho w-$ density of water $\left[\mathrm{kg} / \mathrm{m}^{3}\right]$

Vsc - sea current speed $[\mathrm{m} / \mathrm{s}]$

$\mathrm{Ac}$ - the surface of the underwater part of the ship affected by the sea current $\left[\mathrm{m}^{2}\right]$. 
Impact of sea waves as per formula:

$F s W=\frac{\rho_{W} \cdot g \cdot L \cdot H_{s}^{2}}{16}$

Where are:

$F s w$ - wave force $[\mathrm{N}]$

$\rho \mathrm{w}$ - density of water $\left[\mathrm{kg} / \mathrm{m}^{3}\right]$

$\mathrm{g}$ - gravity constant $\left[\mathrm{m} / \mathrm{s}^{2}\right]$

$L-$ length of a ship [m]

$H s$ - significant wave height [m].

According to above equation, the lateral impact of external forces (wind up to $15 \mathrm{~m} / \mathrm{s}$, currents up to $0.25 \mathrm{~m} / \mathrm{s}$, waves up to $0.5 \mathrm{~m}$ ), on ship with length of $183 \mathrm{~m}$, draft $10.0 \mathrm{~m}$, wind surface area of $2000 \mathrm{~m}^{2}$, generate force of around $45 \mathrm{t}$. This is the lowest value of bollard pull that tugs should have, in static conditions. Taking into account the dynamic environment, also the fact that tugs cannot give $100 \%$ of declared pull and that their efficiency decreases with the strengthening of external factors, required bollard pull for before mentioned case should be no less than $60 \mathrm{t}$.

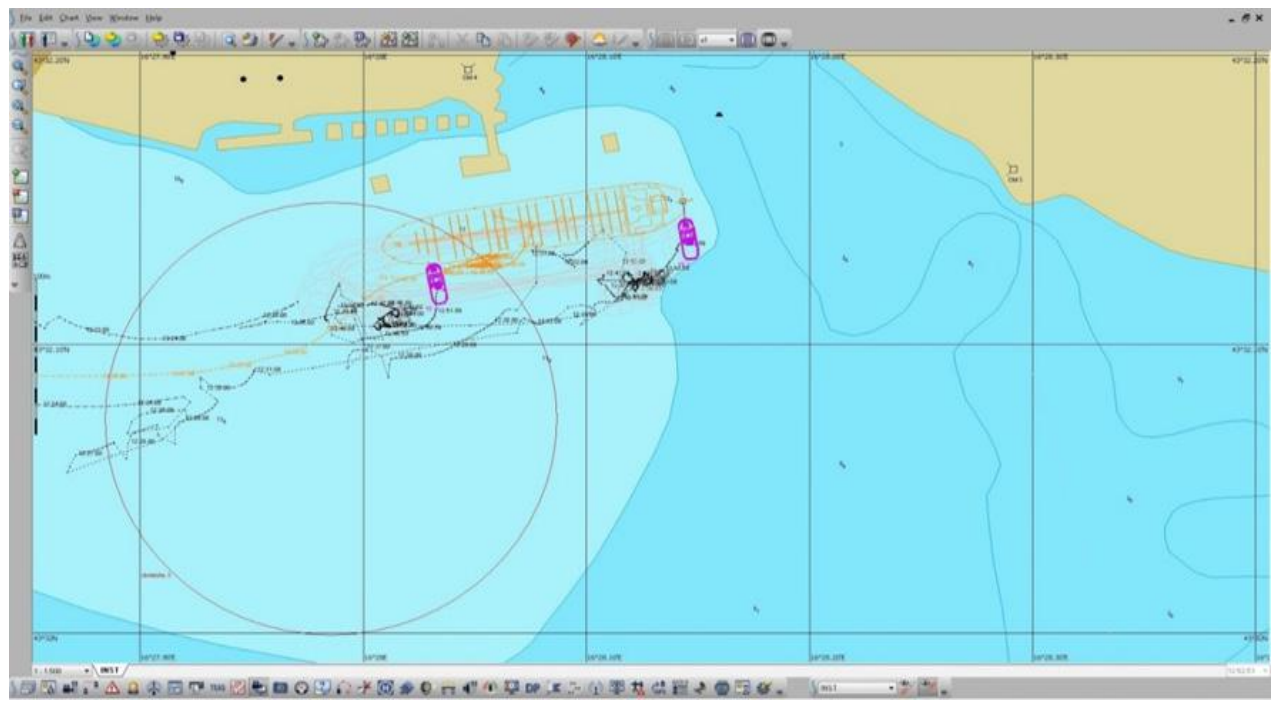

Figure 9. Manoeuvre of berthing for larger ships ${ }^{9)}$

Source: authors using Wartsilla simulator

Now here is shown use of Wartsilla simulator in various weather condition where the tests were conducted by changing wind speed, wind waves and direc- 
tion. Figure 10 shows the manoeuvre of larger tankers (in the example shown, the tanker is $\mathrm{L}=183 \mathrm{~m}$ length and $10.0 \mathrm{~m}$ medium draft - loaded), which manoeuvres and docks at the terminal with the assistance of two tugs. The wind is a constant direction of $040^{\circ}$, speed $15 \mathrm{~m} / \mathrm{s}$, tugs up to $40 \mathrm{tbp}$, waves up to $0,5 \mathrm{~m}$ and currents up to $0,5 \mathrm{kn}$. The tugs actively assist in berthing of tanker on terminal with prior turning and in the final stage a stopping manoeuvre is carried out and pushed to the terminal. The simulation shows that tugs used are in range of required bollard pull and that approach and berthing manoeuvre can be performed in a safe manner, but at the very limit of usability, for lateral wind.

Figure 10. shows the change in transverse and longitudinal speed, which is important in the final stage of berthing, when the speed of the ship should be as close as possible to zero. Furthermore, the same figure shows the change in the direction of the ship's bow which can be used to determine at what angle the ship docks. In the given example, it is recommended as much as possible that the ship has a parallel berthing in direction to the shore, which is also achieved in this example.

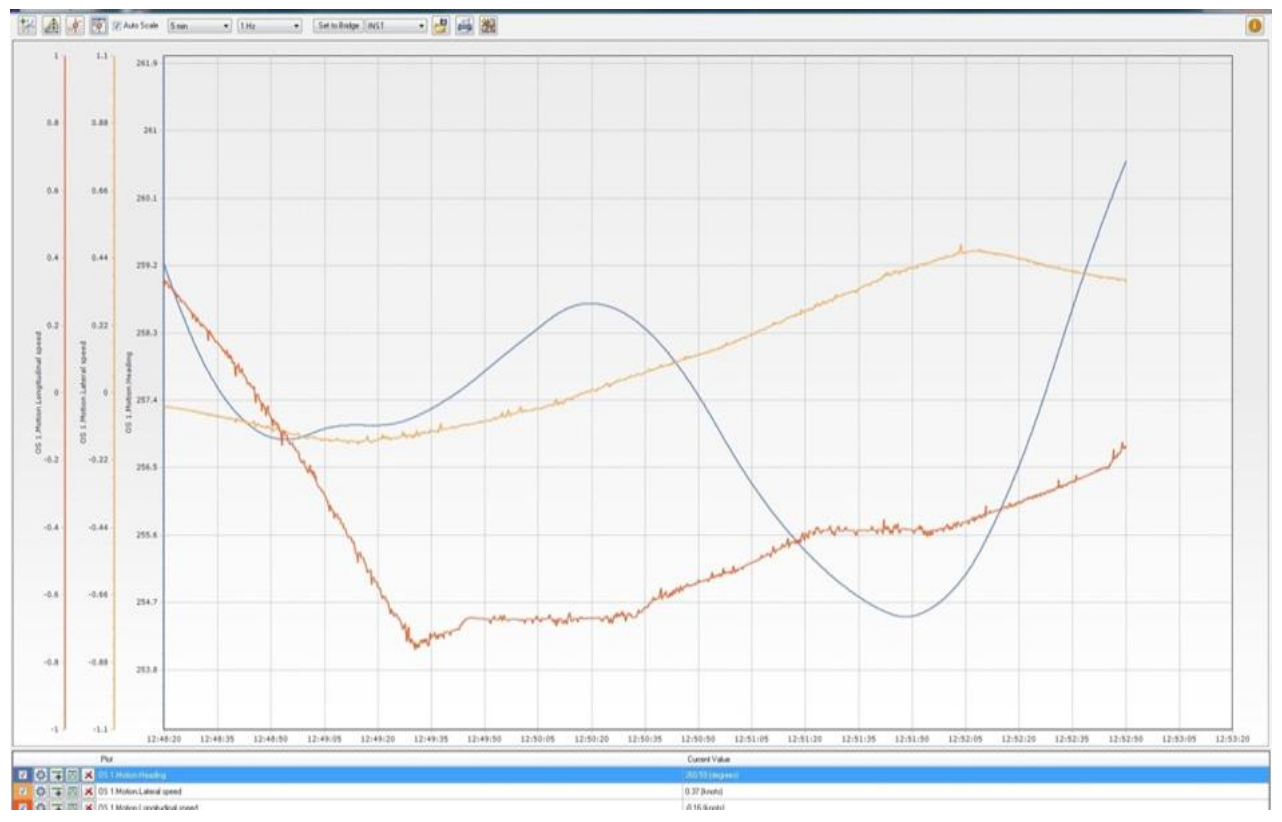

Figure 10. Change of transverse and longitudinal speed ${ }^{9)}$

Source: authors using Wartsilla simulator

Figure 11. shows the current practice of using small tugs in the Port of Split, for assisting tankers of around $200 \mathrm{~m}$ in length. 


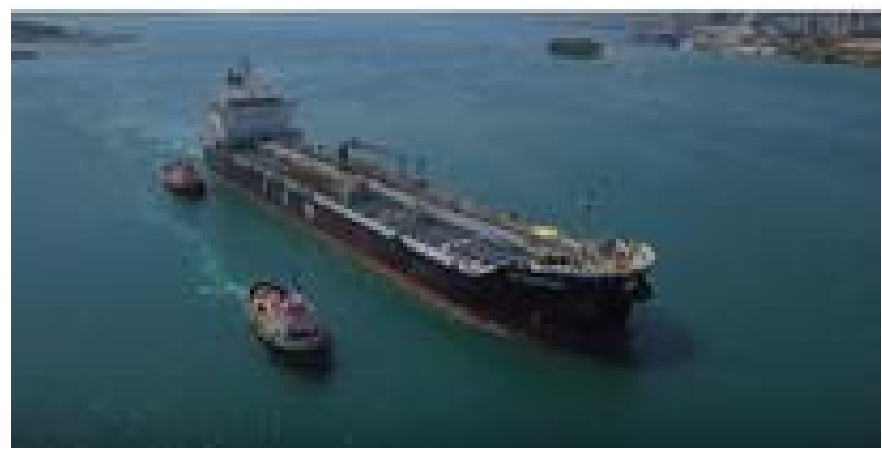

Figure 11. Use of small tugs in the Port of Split, at tanker terminal ${ }^{10)}$

\section{Present practice in choosing optimal number of tugs in various ports}

Calculation and evaluation methods of the optimal request for tugs bollard pull, in particular, port operations, are very important in order to guarantee the navigational safety of the port and ships during the main ship operations in the port (Paulauskas et al. 2021).

In this chapter various examples are given (port of Belfast, port of Gothenburg, port of Cork, port of Omišalj and port of Split). For port of Belfast where mariners are advised that from 1st January 2012 the following minimum towage requirements will be in operation within Belfast Harbour and constitute an update to Belfast Harbour's marine safety management system. These towage requirements are effective for average wind speeds up to 20 knots. For wind speeds in excess of 20 knots, towage requirements will be assessed by the ship's master and pilot and confirmed with harbour master ${ }^{11}$.

Table 3. Number of required tugs for berth $\mathrm{OB} 1$, OB2 and OB3 for Belfast example ${ }^{12)}$

\begin{tabular}{|l|l|l|l|}
\hline \multirow{4}{*}{ Berth } & $\begin{array}{l}\text { Ship } \\
\text { length } \\
\text { overall } \\
(\mathbf{m})\end{array}$ & \multicolumn{2}{|l|}{$\begin{array}{l}\text { Required number and size } \\
\text { of tug bollard pull (tons) }\end{array}$} \\
\cline { 2 - 4 } & $\begin{array}{l}\text { Less than } \\
105 \mathrm{~m}\end{array}$ & $\begin{array}{l}\text { No towage } \\
\text { required }\end{array}$ & $\begin{array}{l}\text { No towage } \\
\text { required }\end{array}$ \\
\hline & $\begin{array}{l}\text { From } \\
105 \mathrm{~m} \text { and } \\
\text { less than } \\
130 \mathrm{~m} \text { with } \\
\text { bow }\end{array}$ & One tug $\geq 20 \mathrm{t}$ & One tug $\geq 10 \mathrm{t}$ \\
OB 1 & & \\
OB 2 & & \\
\hline
\end{tabular}




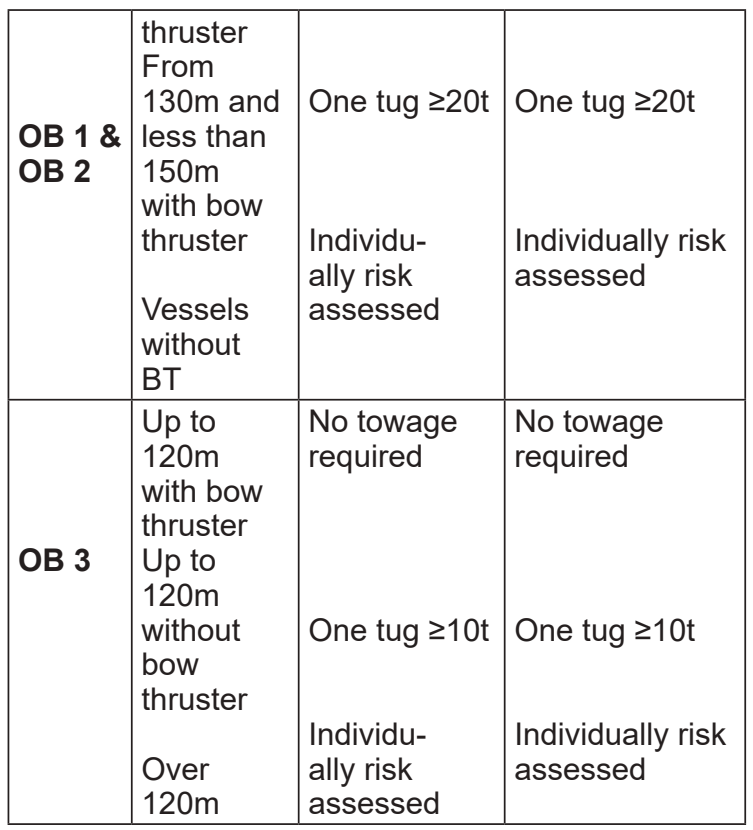

For port of Cork is given table 4. with recommended number of tugs. These towage guidelines are based on the vessels' manoeuvring equipment being fully operational and meteorological conditions not exceeding 20 knots. Any meteorological conditions greater than this will require an assessment to determine the towage requirements ${ }^{13)}$.

Table 4. Number of required tugs for berth City of Quays ${ }^{13)}$

\begin{tabular}{|l|l|l|l|l|l|l|}
\hline Berth & $\begin{array}{l}\text { Vessel } \\
\text { details }\end{array}$ & \multicolumn{2}{|l|}{ Inward } & \multicolumn{2}{l|}{ Outward } & $\begin{array}{l}\text { Escort tug } \\
\text { required }\end{array}$ \\
\hline & & \multicolumn{2}{|l|}{$\mathrm{B} / \mathrm{T}$ No B/T } & \multicolumn{2}{l|}{$\mathrm{B} / \mathrm{T}$ No B/T } & \\
\hline \multirow{3}{*}{$\begin{array}{l}\text { City of } \\
\text { Quays }\end{array}$} & $\begin{array}{l}\text { Loa< } \\
120 \mathrm{~m}\end{array}$ & - & - & - & - & - \\
\cline { 2 - 7 } & $\begin{array}{l}\text { Loa } 120- \\
140 \mathrm{~m}\end{array}$ & - & $\begin{array}{l}1 \text { tug } \\
>12 \mathrm{btp}\end{array}$ & - & $\begin{array}{l}1 \text { tug } \\
>12 \mathrm{btp}\end{array}$ & - \\
\cline { 2 - 7 } & Loa>140m & $\begin{array}{l}1 \text { tug } \\
>30 \mathrm{btp}\end{array}$ & $\begin{array}{l}2 \\
\text { tug>70 } \\
\text { btp }\end{array}$ & $\begin{array}{l}1 \text { tug } \\
>30 \mathrm{btp}\end{array}$ & $\begin{array}{l}2 \text { tug } \\
>70 \\
\text { btp }\end{array}$ & Yes \\
\hline
\end{tabular}

$\mathrm{B} / \mathrm{T}$ meaning is bow thruster 
The tug regulations in Port of Gothenburg are developed in consultation with the Swedish Maritime Administration and stipulate the number of tugboats during arrival and departure in Port of Gothenburg. They are calculated for normal current conditions and wind force of $\max 10 \mathrm{~m} / \mathrm{s}$. When exceeding these normal conditions or other circumstances that could appear, it might be necessary to increase the number of tugboats. For port of Gothenburg is given table 5 on example ${ }^{12}$.

Table 5. Number of required tugs for Gothenburg berth City of Quays - arrival ${ }^{13)}$

\begin{tabular}{|l|c|c|c|c|}
\hline LOA & Bow thruster & $\begin{array}{c}\text { Bow thruster and } \\
\text { high efficient } \\
\text { rudder }\end{array}$ & $\begin{array}{c}\text { Bow and } \\
\text { stern } \\
\text { thruster }\end{array}$ & $\begin{array}{c}\text { Bow thruster } \\
\text { and 2 propeller }\end{array}$ \\
\hline $\mathbf{1 2 0 - 1 3 9 m}$ & 0 & 0 & 0 & 0 \\
\hline $140-\mathbf{1 7 9 m}$ & 1 & 0 & 0 & 0 \\
\hline $\mathbf{1 8 0 - 2 0 9 m}$ & 2 & 2 & 0 & 0 \\
\hline $\begin{array}{l}\mathbf{2 1 0}-\text { and } \\
\text { over }\end{array}$ & 3 & 3 & 1 & 1 \\
\hline
\end{tabular}

In the port of Omišalj ${ }^{14}$, during tanker manoeuvring in normal weather conditions, the following are used:

- 2 tugs for ships up to $180 \mathrm{~m}$ on arrival, and 1 tug on departure;

- 3 tugs for ships from $180-240 \mathrm{~m}$ on arrival, and 2 tugs on departure;

- 4 tugs for ships from $240-280 \mathrm{~m}$ on arrival, and 2 tugs on departure;

- 5-6 tugs for ships over $280 \mathrm{~m}$ on arrival, and 3 tugs on departure.

There is no ordinance regarding the use of tugs in the Port of Split, all is left to the practical experience and assessment of pilots and masters, and eventually the harbour master office. In practice, that means that use of very small tugs (up to 20 bpt) is very common even for largest tankers (up to $200 \mathrm{~m}$ ), weather permitting (figure 11). Tug regulation availability in port of Split is shown in Table 6.

Table 6. Available tugs in port of Split

\begin{tabular}{|l|c|c|c|c|c|}
\hline Tug name & LOA & B & T & Power (kw) & Bollard pull (btp) \\
\hline KASTOR & $29,3 \mathrm{~m}$ & $8,3 \mathrm{~m}$ & $3,2 \mathrm{~m}$ & $2 \times 590 \mathrm{~kW}$ & $20 \mathrm{t}$ \\
\hline RIGEL & $29,3 \mathrm{~m}$ & $8,3 \mathrm{~m}$ & $3,2 \mathrm{~m}$ & $2 \times 590 \mathrm{~kW}$ & $20 \mathrm{t}$ \\
\hline ARGUS & $29,3 \mathrm{~m}$ & $8,3 \mathrm{~m}$ & $3,2 \mathrm{~m}$ & $2 \times 441 \mathrm{~kW}$ & $17 \mathrm{t}$ \\
\hline ALKAID - only on request & $28,0 \mathrm{~m}$ & $8,0 \mathrm{~m}$ & $3,0 \mathrm{~m}$ & $2 \times 906 \mathrm{~kW}$ & $30 \mathrm{t}$ \\
\hline
\end{tabular}

Source: authors 


\section{Discussion}

In this article, the authors present two approaches in determination of minimum strength of tugs. The first approach is computation, which determines the required bollard pull, for worst case scenario of impact of external forces, and with some safety factors, empirically determined. For first approach, the authors are using a model for proper calculation of external factors such as wind force and its impact on ship expressed in $\mathrm{m} / \mathrm{s}$, current direction and speed of current which was observed for particular area during whole year. Impact of sea waves' height is considered and should be calculated.

Another or the second approach is the use of simulators. The second approach is much more reliable, but also much more complex and demanding. Complex and demanding is due to choosing vessel and similarity of types of ships which are commonly entering some area or port basin where the simulation was conducted. Which method will be more reliable depends on results which are compared to those which are computed.

Simulator also shows minimum required number of tugs and minimum bollard pull strength required for different weather conditions. The article can assist masters of ships as additional assistance in practice for some demanding ports in the world and due to this different ports have been selected.

Which will be chosen at the end depends primarily on the capabilities of each port/ administration.

\section{Conclusions}

It is obvious that different ports/authorities have different approach to the use of tugs, and defining their optimal number and size. Usually the weather parameters are crucial, for the specific local area and common type of ships. The calculations of forces for different examples are presented, in which it can be concluded that when choosing the number and strength of required tugs, the size of the ship itself is of primary importance, as well as impact of wind, currents and waves

The effect of external forces is correlated, except with the size of the ship (displacement, draft, length) especially with the surface of the above water part and underwater part of the ship. Due to the increased moment, the ship also loses stability. To compensate for forces which are acting on the ship and the docking of the ship, it is important to select the optimal number of tugs so that the possible risk that arises is reduced to the required level to safely complete operation of berthing/un-berthing.

It is certainly recommended that the administration prescribes the minimum conditions for the use of tugs, otherwise the logic of the market and the pursuit of the lowest possible costs will undoubtedly jeopardize safety.

\section{NOTES}

1. International Maritime Dangerous Goods, Volume 1, 2020 edition, IMO publishing.

2. International Maritime Dangerous Goods. Volume 2, 2020 edition, IMO publishing. 
3. International Organization of Masters, Mates \& Pilots, an organization of Maritime professionals. Available from: http://www.bridgedeck.org, available on 03 May 2021.

4. Guidelines for Safe Harbour Towage Operations. European Tug Owners Association, February 2015.

5. Ship Manoeuvre Theory, Force Technology, Division of Maritime Industry (DMI). Lyngby, 2003

6. Offshore support vessel developments for deep water oil and gas, https://www.osti.gov/ etdeweb/servlets/purl/21150468, available on 01-April 2021.

7. The Japan Ship Owners' Mutual Protection \& Indemnity Association - Loss Prevention and Ship Inspection Department, 2013. \& NYK Line SMS Manual, 2013

8. D-0030 Guidelines for Marine Transportations, 2017.

9. Wartsilla simulators - ver. NTPRO 5000

10. Ship spotting, https://www.youtube.com/watch?v=dcB01t-sMFI (16 March 2021).

11. Towage Information - Belfast Harbour. Available: https://www.belfast-harbour.co.uk (15 April 2021).

12. Towage - Port of Cork. Available: https://www.portofcork.iesindex.cfm (01 May 2021).

13. Tug regulation - Port of Gothenburg. Available from: https://www.portofgothenburg. com/maritime/tug-regulations-for-the-port-of-gothenburg (18 April 2021).

14. Rules of procedure in the port and terms of use at the basin for port of Omišalj, in the area under the management of the port authority of Rijeka, port authority of Rijeka, 2004.

\section{REFERENCES}

Paulauskas, V. et al., 2021. The Influence of Port Tugs on Improving the Navigational Safety of the Port. Journal of Marine Science and Engineering $M D P I, 1-2$.

$\checkmark$ Rino Bošnjak https://orcid.org/0000-0002-1795-333X

Zvonimir Lušić https://orcid.org/0000-0002-4118-4761

Filip Bojić https://orcid.org/0000-0002-9706-200X

Dario Medić https://orcid.org/0000-0002-4455-0851

Faculty of Maritime Studies University of Split Split, Croatia E-mail: rino.bosnjak@pfst.hr

E-mail: zlusic@pfst.hr E-mail: filip.bojic@pfst.hr E-mail: dario.medic@pfst.hr 